\title{
In vivo Evaluation of Zirconia Abutments in Implant supported Restorations in Partially Edentulous Patients
}

\author{
${ }^{1}$ Anita Kapri, ${ }^{2}$ Arun Gupta, ${ }^{3}$ Sudhir Joshi
}

\begin{abstract}
Dental implants have been a universally accepted option for prosthetic rehabilitation of partially edentulous patients. Titanium implants abutments exhibit a dull grayish hue and give an unnatural appearance. Abutments based on zirconia are one of the alternatives to titanium abutments. To date, few comparative studies have reported on esthetic and biological outcomes of implant-supported restorations with zirconia abutments.
\end{abstract}

Purpose: To clinically evaluate the esthetic performance of zirconia abutments in implant-supported restorations.

Materials and methods: A total of 24 anterior implant sites were chosen for the placement of implants. A delayed loading protocol was followed; 12 zirconia abutments were placed along with 12 titanium abutments in the contralateral sites. Biological and esthetic variables were recorded by a periodontist and prosthodontist. The patients were followed 2 weeks, 1, 3, and 6 months postinsertion.

Results: All the data for Copenhagen index score and visual analog scale scores were evaluated by the prosthodontist at follow-up appointments; the means were tabulated. The data were statistically analyzed using Statistical Package for the Social Sciences software utilizing paired t-test; $p$ value was found to be significant for all parameters except distal papilla and symmetry, which showed $p=0.257$ and $p=0.110$ respectively.

Conclusion: According to the results of this study, esthetic performances of zirconia abutment in implant-supported restorations were determined to be higher than those values associated with titanium abutments.

Keywords: Esthetic abutments, Implant esthetics, Titanium abutment, Zirconia.

How to cite this article: Kapri A, Gupta A, Joshi S. In vivo Evaluation of Zirconia Abutments in Implant supported Restorations in Partially Edentulous Patients. J Contemp Dent 2017;7(1):35-42

Source of support: Armed Forces Medical Research Fund Conflict of interest: None

\footnotetext{
${ }^{1-3}$ Reader

${ }^{1}$ Department of Prosthodontics, Naval Institute of Dental Sciences, Mumbai, Maharashtra, India

${ }^{2}$ Department of Preventive and Social Medicine, INHS Asvini Mumbai, Maharashtra, India

${ }^{3}$ Department of Cardiologist, INHS Asvini, Mumbai, Maharashtra India

Corresponding Author: Anita Kapri, Reader, Department of Prosthodontics, Naval Institute of Dental Sciences, Mumbai Maharashtra, India, Phone: +912222147060, e-mail: a.kapri@ rediffmail.com
}

\section{INTRODUCTION}

Abutments and dental implants were usually fabricated out of commercially pure titanium. ${ }^{1}$ Titanium has demonstrated good biocompatibility and mechanical properties. ${ }^{2}$ However, from an esthetic point of view, titanium abutments sometimes result in an abnormal bluish hue to the soft tissue. ${ }^{3}$ Hence, for achieving optimal mucogingival esthetics, there was a need for tooth colored abutments. ${ }^{4}$ With increased demand for esthetic restorations, tooth colored abutment materials have gained popularity ${ }^{5-7}$ Among the various tooth colored materials used for abutments are alumina, combination of zirconia and titanium, or purely zirconia ceramics. ${ }^{8}$ Alumina showed promise but had a drawback of fracturing near the neck of the abutment due to its poor flexural strength. ${ }^{9}$ Abutments and crowns fabricated from zirconia are one of the most recent alternatives to metal abutments. ${ }^{10}$ Until now, there have not been many in vivo studies or randomized control trials that have assessed the biologic and esthetic variables related to zirconia-based implant-supported restorations. Hence, this study was designed to evaluate the esthetic and biological aspects of zirconia abutments in vivo.

The aim of this study was to evaluate the clinical performance of zirconia abutment-based implantsupported restorations in partially edentulous patients. The objectives were to evaluate the clinical results of zirconia vs titanium abutments in implant-supported restorations in terms of esthetic and biologic outcomes. The primary research question was whether zirconia abutments resulted in better esthetic and biologic outcomes in implant-supported restorations in clinical situations. The study was carried out for 4 years. The recent scientific literature showed very few comparative studies have been reported on esthetic and biological outcomes of implant-supported restorations using zirconia abutments. Zirconia abutments, if successful, could be used as a viable treatment option to rehabilitate those who are afflicted with partial edentulism, especially in esthetic zone.

In 1993, a novel ceramic abutment (CerAdapt, Nobel Biocare), which was made of densely sintered alumina, was introduced for Brånemark system implants (Nobel Biocare) ${ }^{5-7}$ It was indicated for single crowns and fixed partial dentures (FPDs) in anterior teeth including 
premolar regions with documented evidence of encouraging results with prospective clinical studies. ${ }^{11,12}$

Furthermore, abutments made of densely sintered yttrium-stabilized zirconia were introduced for use as support for implant-supported single-tooth crowns. ${ }^{13,14}$ Alumina as well as zirconia was characterized by tissue compatibility, ${ }^{15}$ low corrosion potential, low thermal conductivity, and superior mechanical properties compared with conventional ceramics. ${ }^{16-19}$ Moreover, zirconia has a flexural strength and fracture toughness almost twice as high as alumina. ${ }^{20}$ Zirconia has been considered to be a promising ceramic abutment as it has high flexural strength (1,400 MPa) and desirable optical properties. Through its common use in orthopedics (e.g., hip joint replacements) for many years, the biocompatibility of zirconia has been extensively documented. ${ }^{21,22}$ Zirconia abutments are either prefabricated or custom made. ${ }^{23}$

Scarano et $\mathrm{al}^{24}$ reported that the degree of coverage by bacteria was $12 \%$ for zirconia and $19 \%$ for titanium surfaces in vivo. They demonstrated that zirconium oxide is a suitable material for implant abutments with a low colonization potential. Manicone et $\mathrm{al}^{25}$ presented a systematic overview on zirconia ceramics and indicated a high success rate for zirconia FPDs and zirconia implant abutments. Rimondini et $\mathrm{al}^{26}$ suggested in vitro yttria-tetragonal zirconia polycrystal accumulated fewer bacteria than Ti in terms of total number of bacteria and presence of potential putative pathogens, such as rods. Nascimento et $\mathrm{al}^{27}$ found significant difference in total cell count of Candida species between commercially pure titanium and machined pure titanium. An in vivo animal study analyzed soft tissue responses to implant abutments made of titanium, $\mathrm{ZrO}_{2}, \mathrm{Ti}$, and Au-Pt alloy and established no difference in the soft tissue dimensions between $\mathrm{Ti}$ and $\mathrm{ZrO}_{2}$ abutments at 2 and 5 months of healing, but a significant difference was found between the two materials and Au-Pt alloy. ${ }^{28}$ Similarly, Kohal et al ${ }^{4}$ found no difference in soft tissue integration around rough titanium and zirconia implants in a monkey model. Lima et $\mathrm{al}^{29}$ and Al-Ahmad et $\mathrm{al}^{30}$ found that Ti and $\mathrm{ZrO}_{2}$ surfaces displayed similar biological properties in terms of biofilm composition and bacterial adherence. The attachment, growth pattern, and the hereditic effect of human gingival fibroblasts cultivated on titanium and different zirconia surfaces (smooth and rough) were also investigated. Human gingival fibroblast showed equivalent biological responses to both grooved zirconia ceramic and pure titanium surfaces. ${ }^{31}$ van Brakel et al $^{32}$ compared the health of the soft tissues toward zirconia and titanium abutments in man, as observed using histological data. No differences in soft tissue health were seen in peri-implant soft tissue adjacent to zirconia and titanium abutment surfaces. Zirconia abutments also showed a high level of precision fit. ${ }^{33}$ With standard internal diameter trichannel connection implants, the maximum load capacity of zirconia abutment was significantly higher than that of the other commercial alumina-based abutments. ${ }^{34}$

In a systematic review of in vivo studies of implantsupported restorations by Sailer et $\mathrm{al}^{35}$ the rate of marginal bone level exceeding $2 \mathrm{~mm}$ was higher for implants supporting metal than for those supporting ceramic abutments. In that systematic review, metal abutments referred to both gold alloy and titanium abutments, and ceramic abutments referred to oxide ceramics, i.e., alumina and zirconia abutments. Rimondini et $\mathrm{al}^{26}$ reported lower accumulation and colonization of bacterial plaque on zirconia than on titanium surfaces while comparing plaque accumulation on abutments. Few patients and clinicians have different views regarding esthetics of a restoration. ${ }^{36}$ Distal papilla measurements were less reliable than mesial, which may be due to practical limitations to reproduce the distal papilla by photographs. ${ }^{37}$ Gingiva biotype and cervical dimension of abutment would also influence papilla dimension. ${ }^{38,39}$

\section{MATERIALS AND METHODS}

The study was carried out on consenting patients aged 18 years or more who had at least two teeth missing in the anterior esthetic zone and desired implant-supported restorations. The inclusion criteria were patients who required tooth replacements with implant-supported restorations, had no contraindications for oral implant treatment, e.g., uncontrolled diabetes, metabolic bone disorders, past radiotherapy in head and neck, current chemotherapy, or other diseases with an influence on bone healing, and who would participate in followup examinations. The study sample was to include 24 implant sites. These sites need to be fully healed (teeth extracted/lost $>4$ months before implant placement), have adequate bone quality and quantity, have adequate gingival biotype of 1.5 to $2 \mathrm{~mm}$ thickness, and opposed by natural teeth or a fixed prosthesis.

The exclusion criteria included conditions requiring chronic antibiotics or steroids, renal failure, severe or uncontrolled metabolic disorder, alcoholism or drug abuse, human immunodeficiency virus infection or smoking $>10$ cigarettes per day or chewing tobacco, and severe bruxism/clenching or persistent intraoral infection.

Eligible patients would be assessed by clinical examination, medical and dental history, and radiographs (Fig. 1). The clinical and radiological registrations (both panoramic and intraoral periapical radiographs) were performed intra- and postoperatively (Fig. 2). Surgery was performed with local anesthesia under aseptic conditions in an outpatient environment, following the standard flap or flapless technique and abiding by the manufacturer's 


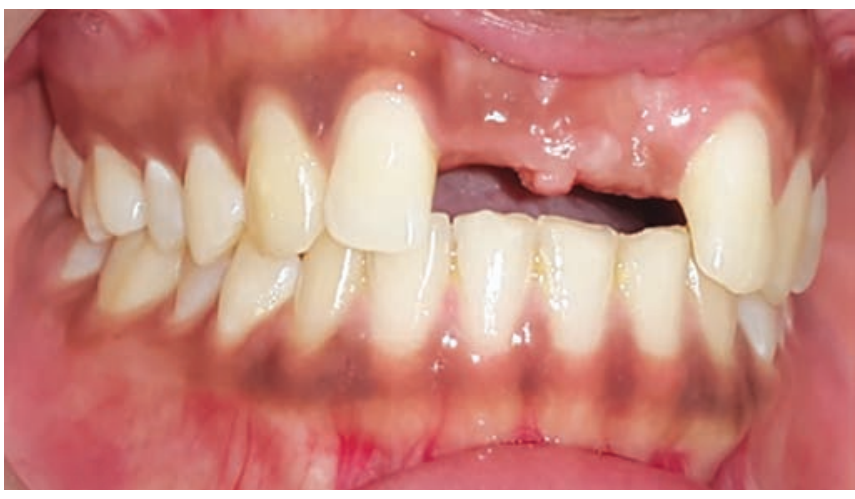

Fig. 1: Preoperative evaluation

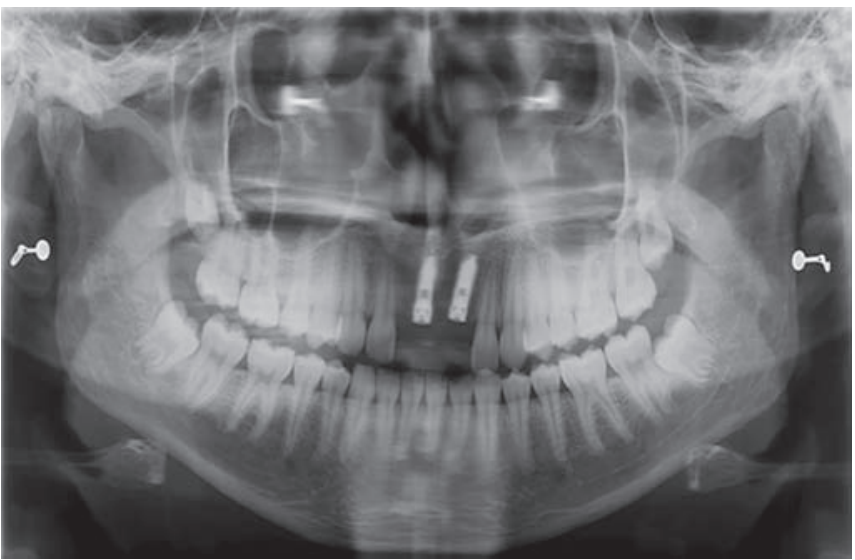

Fig. 3: Implant placement orthopantomogram

recommendation on sequential steps in implant placement. Implants were from AB Dental Company, Israel, ranging from 3.3 to $3.5 \mathrm{~mm}$ in diameter and 10 to 11.5 $\mathrm{mm}$ in length. Any implant lacking primary stability when tested intraoperatively by clinically checking for mobility with the help of blunt-ended instruments was excluded from further study participation. Patients with inadequate bone during surgery were excluded.

The delayed loading protocol was followed for the purpose of the study. Implant site allocation for control or experimental group was done randomly. Healing abutments were placed after 3 months of implant placement. Impressions were made with elastomeric impression materials using impression copings. Twelve anterior implant sites were selected for zirconia abutments and 12 anterior implant sites for titanium abutments, which were used as controls (Fig. 3). The abutments were manufactured by ALB Surgicals (West Patel Nagar, New Delhi, India) with AB implants, Israel. The abutments were placed 2 weeks after healing abutment placement (Fig. 4). The restorations were fabricated thereafter with all ceramic crowns (Fig. 5). All anterior implant sites with zirconia abutments received all ceramic crowns. Biological variables in terms of modified plaque index and esthetic variables (in terms of five criteria of Copenhagen index)

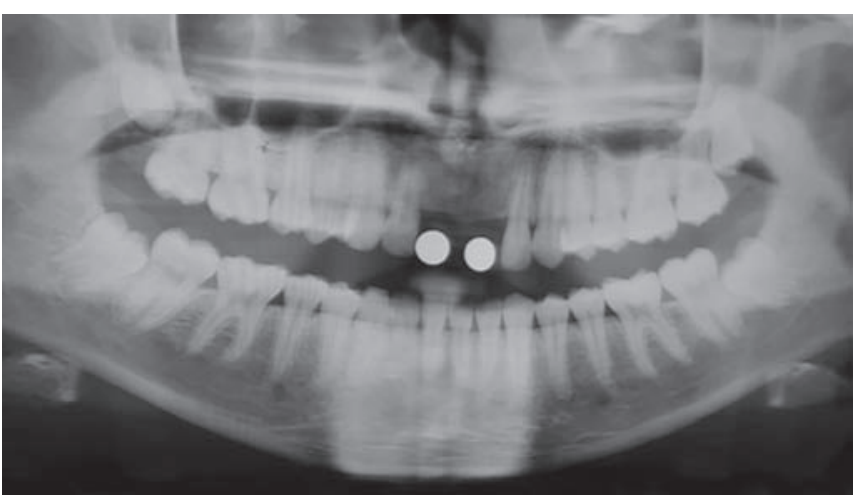

Fig. 2: Preoperative orthopantomogram

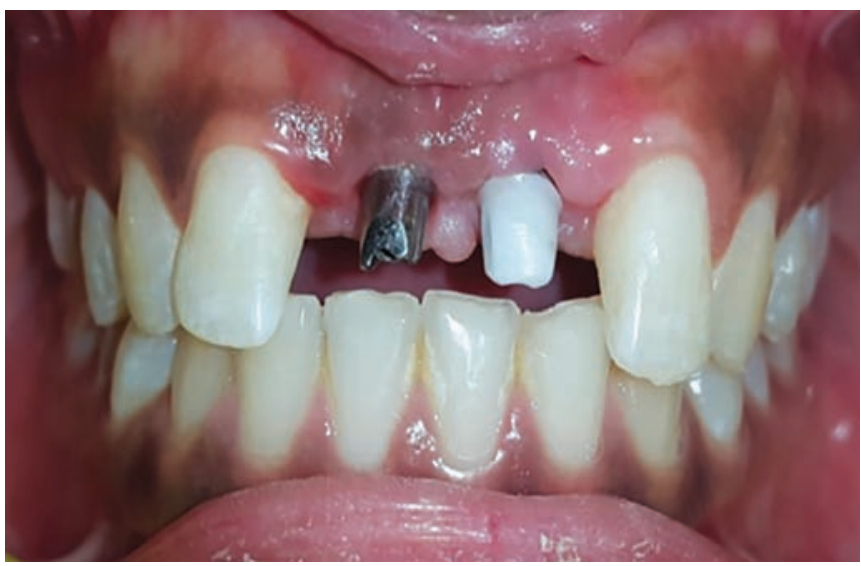

Fig. 4: Tooth 11 with titanium abutment and tooth 21 with zirconia abutment

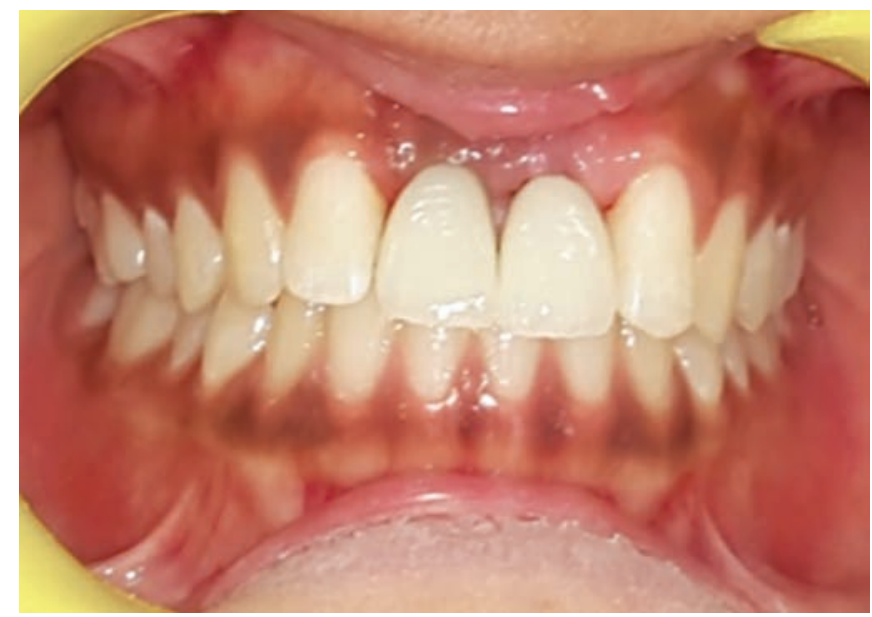

Fig. 5: Postoperative intraoral

were recorded by a periodontist and prosthodontist. Variables for Copenhagen index score (CIS) were crown morphology, crown color match, symmetry, mucosal discoloration, and mesial and distal papilla. The examiners were calibrated using dental examination calibration procedure manual (Columbus State Community College) with weighted kappa 0.64 to $1.00 .^{40}$ The patients were followed up after 2 weeks, 1, 3, and 6 months.

The implants placed were evaluated clinically and radiologically. Criteria for the evaluation were as follows: 
Table 1: Modified plaque index ${ }^{23}$

0: No detection of plaque
1: Plaque only recognized by running a probe across the
smooth marginal surface of implant
2: Plaque can be seen by naked eye
3: Abundance of soft matter

Table 2: Copenhagen index score ${ }^{24}$

\begin{tabular}{|c|c|}
\hline \multicolumn{2}{|c|}{ Copenhagen Index Score } \\
\hline \multirow[t]{2}{*}{$\begin{array}{l}\text { Harmony and } \\
\text { symmetry }\end{array}$} & $\begin{array}{l}\text { According to facial midline, the tooth axis, and } \\
\text { the smile line }\end{array}$ \\
\hline & $\begin{array}{l}\text { Score 1: Optimal symmetry, Score } 2 \text { : Almost } \\
\text { symmetry, Score } 3 \text { : Asymmetric, Score } 4 \text { : Very } \\
\text { asymmetric }\end{array}$ \\
\hline \multirow[t]{2}{*}{$\begin{array}{l}\text { Crown } \\
\text { morphology }\end{array}$} & $\begin{array}{l}\text { Based on "Ideal Shape" with regards to } \\
\text { prominences, surface contours and dimensions } \\
\text { of the crown compared with contralateral natural } \\
\text { tooth }\end{array}$ \\
\hline & $\begin{array}{l}\text { Score 1: Optimal, Score 2: Almost optimal, } \\
\text { Score 3: Suboptimal, Score 4: Unacceptable }\end{array}$ \\
\hline \multirow[t]{2}{*}{$\begin{array}{l}\text { Color match } \\
\text { of the crown }\end{array}$} & $\begin{array}{l}\text { Comparison of the hue, value, chroma and } \\
\text { transluency to natural dentition }\end{array}$ \\
\hline & $\begin{array}{l}\text { Score 1: Optimal, Score: 2: Almost optimal, } \\
\text { Score 3: Suboptimal, Score 4: Unacceptable }\end{array}$ \\
\hline \multirow{2}{*}{$\begin{array}{l}\text { Discoloration } \\
\text { of buccal } \\
\text { mucosa }\end{array}$} & $\begin{array}{l}\text { The degree of grayish discoloration of marginal } \\
\text { mucosa }\end{array}$ \\
\hline & $\begin{array}{l}\text { Score 1: No discoloration, Score 2: Light grayish, } \\
\text { Score 3: Distinct greyish, Score 4: Visible metal }\end{array}$ \\
\hline \multirow[t]{2}{*}{ Papilla level } & The papilla height mesially and distally \\
\hline & $\begin{array}{l}\text { Score 1: Papilla filled the entire proximal space, } \\
\text { Score 2: At least } 1 / 2 \text { the height of papilla was } \\
\text { present, Score } 3 \text { : Less than } 1 / 2 \text { the height of } \\
\text { papilla but there was a convex curvature of } \\
\text { papilla present, Score } 4 \text { : No papilla. }\end{array}$ \\
\hline
\end{tabular}

Biological variables were recorded in terms of modified plaque index (Table 1$)^{41}$ and esthetic variables were recorded in terms of CIS (Table 2) ${ }^{42}$ and visual analog scale (VAS) (Table 3). ${ }^{43}$

\section{RESULTS}

All patients selected returned for recalls. All the data for modified plaque index were recorded with the help of periodontal probe and a disclosing solution at the follow-up visits after 3 weeks, 1, 3, and 6 months, and their mean was tabulated by the periodontist (Table 4). All the data for CIS and VAS scores were evaluated by the prosthodontist and the periodontist at follow-up appointments and their mean tabulated as shown in

Table 3: Overall CIS and VAS score ${ }^{25}$

\begin{tabular}{lll}
\hline SI. no. & Overall CIS & Visual analog score \\
\hline 1 & Excellent & Very bad esthetics \\
2 & Very good & Bad esthetics \\
3 & Good & Average esthetics \\
4 & Poor & Good esthetics \\
5 & Very poor & Very good esthetics \\
\hline
\end{tabular}

Table 4: Modified plaque index scores

\begin{tabular}{cllll}
\hline $\begin{array}{c}\text { No. of } \\
\text { cases }\end{array}$ & Patient's name & Teeth no. & $\begin{array}{l}\text { ZR-based } \\
\text { restoration }\end{array}$ & $\begin{array}{l}\text { Ti-based } \\
\text { restoration }\end{array}$ \\
\hline 1 & Zuala & 11,21 & 0 & 0 \\
2 & Nehal & 11,21 & 0 & 1 \\
3 & Do Virender & 21,22 & 0 & 1 \\
4 & Vinod & 11,21 & 1 & 1 \\
5 & Renu Singhal & $11,21,22,23$ & 1 & 1 \\
6 & Madhu Gupta & $11,21,22$ & 1 & 1 \\
7 & Arvind & 11,21 & 1 & 1 \\
8 & V K Syal & 11,21 & 2 & 2 \\
9 & R P Singh & 11,21 & 1 & 1 \\
10 & Wo Rathore & 11,21 & 0 & 0 \\
11 & Sgt Vinay & 11,21 & 0 & 0 \\
12 & Sep Narayan & 11,21 & 0 & 1 \\
\hline
\end{tabular}

Tables 5 and 6 . The data were then statistically analyzed using Statistical Package for the Social Sciences software utilizing paired t-test (Tables 7 and 8); $p$ value was found to be significant for all parameters except distal papilla and symmetry. Graphical representation of modified plaque index and VAS is shown in Graphs 1 and 2. Graph 3 shows the graphical representation of all the six parameters of CIS.

\section{DISCUSSION}

The study results showed modified plaque indices and VAS scores with highly significant results $(p=0.000)$. Among the CIS criteria, all the criteria showed significant results, with mucosal discolorations and crown color match showing highly significant $p$-value $=0.000$ except distal papilla measurements that showed $\mathrm{p}=0.257$ and symmetry showing $\mathrm{p}=0.110$, which were not significant. These results showed that only distal papilla and symmetry measurements had no effect on titanium or zirconia abutments. Distal papilla measurements were less reliable than mesial, which may be due to practical limitations to reproduce the distal papilla by photographs. ${ }^{37}$ Gingiva biotype and cervical dimension of abutment would also influence papilla dimension. ${ }^{38,39}$

The study results showed zirconia abutments retained less plaque than titanium abutments as zirconia abutments may represent a material surface less attractive or smoother for plaque retention compared with titanium. According to Andersson and Odén ${ }^{16}$ zirconia generates more stable peri-implant soft tissue and hence, less plaque retention. The material properties, surface roughness, and glass content also allowed less plaque retention than titanium. This result is in accordance with that of Meier et al. ${ }^{17}$ The study results also showed better esthetics in zirconia abutments than titanium surfaces. This can also be accepted in terms of better soft tissue emergence profile and better maintenance of interdental 
In vivo Evaluation of Zirconia Abutments in Implant supported Restorations in Partially Edentulous Patients

Table 5: Copenhagen index score

\begin{tabular}{|c|c|c|c|c|c|c|c|c|c|c|c|c|}
\hline \multirow{2}{*}{$\begin{array}{l}\text { No. of } \\
\text { cases }\end{array}$} & \multicolumn{2}{|c|}{ Crown morphology } & \multicolumn{2}{|c|}{$\begin{array}{c}\text { Crown color } \\
\text { match }\end{array}$} & \multicolumn{2}{|c|}{$\begin{array}{c}\text { Mucosal } \\
\text { discoloration }\end{array}$} & \multicolumn{2}{|c|}{ Mesial papilla } & \multicolumn{2}{|c|}{ Distal papilla } & \multicolumn{2}{|c|}{ Symmetry } \\
\hline & With $\mathrm{Zr}$ & With Ti & With Zr & With Ti & With Zr & With $\mathrm{Ti}$ & With $\mathrm{Zr}$ & With Ti & With Zr & With Ti & With Zr & With Ti \\
\hline 1 & 1 & 1 & 1 & 2 & 1 & 3 & 1 & 1 & 2 & 1 & 1 & 2 \\
\hline 2 & 1 & 1 & 1 & 2 & 1 & 3 & 1 & 1 & 1 & 1 & 2 & 2 \\
\hline 3 & 1 & 1 & 1 & 2 & 2 & 3 & 1 & 1 & 1 & 1 & 1 & 2 \\
\hline 4 & 1 & 1 & 1 & 2 & 2 & 3 & 2 & 2 & 2 & 1 & 1 & 2 \\
\hline 5 & 2 & 2 & 1 & 3 & 3 & 4 & 2 & 2 & 1 & 2 & 1 & 1 \\
\hline 6 & 2 & 2 & 1 & 3 & 3 & 4 & 2 & 1 & 1 & 1 & 2 & 1 \\
\hline 7 & 2 & 2 & 2 & 3 & 2 & 3 & 2 & 1 & 1 & 1 & 2 & 2 \\
\hline 8 & 2 & 3 & 2 & 3 & 2 & 3 & 2 & 1 & 1 & 1 & 1 & 2 \\
\hline 9 & 1 & 1 & 1 & 2 & 1 & 2 & 2 & 2 & 2 & 1 & 1 & 2 \\
\hline 10 & 1 & 1 & 1 & 2 & 1 & 3 & 2 & 2 & 1 & 2 & 2 & 1 \\
\hline 11 & 1 & 2 & 1 & 2 & 2 & 3 & 2 & 2 & 2 & 1 & 1 & 1 \\
\hline 12 & 1 & 2 & 1 & 3 & 2 & 3 & 2 & 1 & 1 & 1 & 1 & 1 \\
\hline
\end{tabular}

Table 6: Visual analog scale scores

\begin{tabular}{cllll}
\hline & & & $\begin{array}{l}\text { Implant } \\
\text { restoration } \\
\text { over } \\
\text { zirconia }\end{array}$ & $\begin{array}{l}\text { Implant } \\
\text { restoration } \\
\text { over } \\
\text { titanium } \\
\text { abutment }\end{array}$ \\
cases & Patient's name & Teeth no. & abutment \\
\hline 1 & Zuala & 11,21 & 5 & 4 \\
2 & Nehal & 11,21 & 5 & 4 \\
3 & Do Virender & 21,22 & 5 & 4 \\
4 & Vinod & 11,21 & 5 & 3 \\
5 & Renu Singhal & $11,21,22,23$ & 3 & 3 \\
6 & Madhu Gupta & $11,21,22$ & 3 & 3 \\
7 & Arvind & 11,21 & 4 & 3 \\
8 & V K Syal & 11,21 & 3 & 3 \\
9 & R P Singh & 11,21 & 5 & 3 \\
10 & Wo Rathore & 11,21 & 5 & 4 \\
11 & Sgt Vinay & 11,21 & 5 & 4 \\
12 & Sep Narayan & 11,21 & 5 & 4 \\
\hline
\end{tabular}

Table 7: Paired sample statistics

\begin{tabular}{lllll}
\hline Parameter & Abutment & Mean & $\begin{array}{l}\text { Std. } \\
\text { deviation }\end{array}$ & $\begin{array}{l}\text { Std. error } \\
\text { mean }\end{array}$ \\
\hline Symmetry & With Zr & 1.3333 & 0.48154 & 0.09829 \\
& With Ti & 1.5833 & 0.50361 & 0.10280 \\
Mucosal & With Zr & 1.8333 & 0.70196 & 0.14329 \\
discoloration & With Ti & 3.0833 & 0.50361 & 0.10280 \\
Crown & With Zr & 1.3333 & 0.48154 & 0.09829 \\
morphology & With Ti & 1.5033 & 0.65386 & 0.13347 \\
Mesial papilla & With Zr & 1.7500 & 0.44233 & 0.09029 \\
& With Ti & 1.4167 & 0.50361 & 0.10280 \\
Distal papilla & With Zr & 1.3333 & 0.48154 & 0.09829 \\
& With Ti & 1.1667 & 0.38069 & 0.07771 \\
Crown color & With Zr & 1.1667 & 0.38069 & 0.07771 \\
match & With Ti & 2.4167 & 0.50361 & 0.10280 \\
Visual analog & With Zr & 4.4167 & 0.88055 & 0.17974 \\
scale scores & With Ti & 3.5000 & 0.51075 & 0.10426 \\
Modified plaque & With Zr & 0.5833 & 0.65386 & 0.13347 \\
index & With Ti & 0.8333 & 0.56466 & 0.11526 \\
Overall CIS & With Zr & 8.5833 & 1.74248 & 0.35568 \\
& With Ti & 11.250 & 1.25974 & 0.25714 \\
\hline
\end{tabular}

Table 8: Paired sample t-test

\begin{tabular}{|c|c|c|c|c|c|c|c|c|}
\hline \multirow[b]{2}{*}{ Parameter } & \multirow[b]{2}{*}{ Mean } & \multirow[b]{2}{*}{ Std deviation } & \multirow{2}{*}{$\begin{array}{l}\text { Std error } \\
\text { mean }\end{array}$} & \multicolumn{2}{|c|}{$95 \% \mathrm{Cl}$ of the difference } & \multirow[b]{2}{*}{$t$-value } & \multirow[b]{2}{*}{$d f$} & \multirow{2}{*}{$\begin{array}{l}\text { Sig } \\
\text { (2-tailed) }\end{array}$} \\
\hline & & & & Lower & Upper & & & \\
\hline Modified plaque index & -2.5000 & 0.44233 & 0.09029 & -0.43678 & -0.06322 & -2.769 & 23 & 0.011 \\
\hline CIS overall & -2.66667 & 1.12932 & 0.23052 & -3.14354 & -2.18980 & -11.568 & 23 & 0.000 \\
\hline Visual analog scale scores & 0.91667 & 0.65386 & 0.13347 & 0.64056 & 1.19277 & 6.868 & 23 & 0.000 \\
\hline Crown morphology & -0.25000 & 0.44233 & 0.09029 & -0.43678 & -0.06322 & -2.769 & 23 & 0.011 \\
\hline Crown color match & -1.25000 & 0.44233 & 0.09029 & -1.43678 & -1.06322 & -13.844 & 23 & 0.000 \\
\hline Mucosal discoloration & -1.25000 & 0.44233 & 0.09029 & -1.43678 & -1.06322 & -13.844 & 23 & 0.000 \\
\hline Mesial papilla & 0.33333 & 0.48154 & 0.09829 & 0.13000 & 0.53667 & 3.391 & 23 & 0.003 \\
\hline Distal papilla & 0.16667 & 0.70196 & 0.14329 & -0.12975 & 0.46308 & 1.163 & 23 & 0.257 \\
\hline Symmetry & -0.25000 & 0.73721 & 0.15048 & -0.56130 & 0.06130 & -1.661 & 23 & 0.110 \\
\hline
\end{tabular}

papilla with zirconia abutments, thereby resulting in better esthetics.

One of the limitations of this study is that it was not a long-term study; the study period was only 4 years. Longterm study would be required to validate the results.
Also, further only one prosthodontist and periodontist evaluated the outcomes, and patient-reported outcomes were not taken into consideration.

The cumulative incidence of biological complications after 5 years was estimated at 5.2\% (95\% confidence 


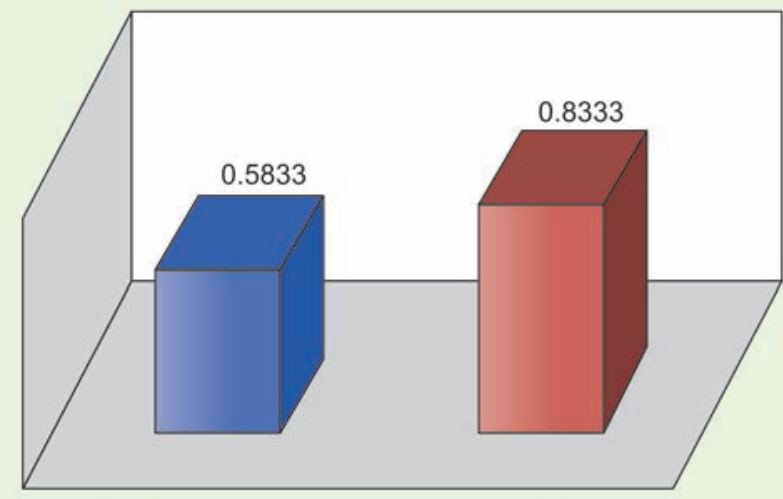

Zirconia abutment

Graph 1: Modified plaque index
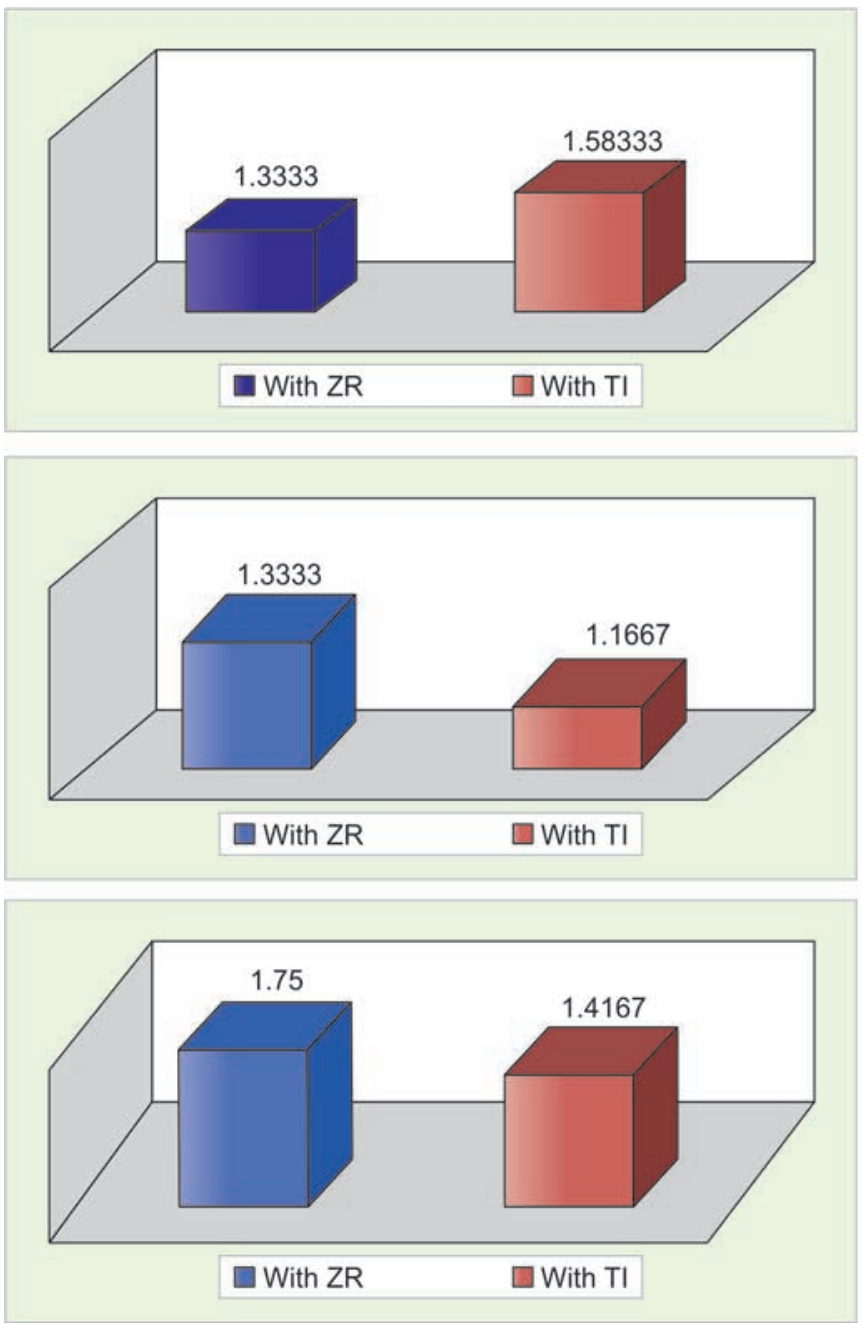

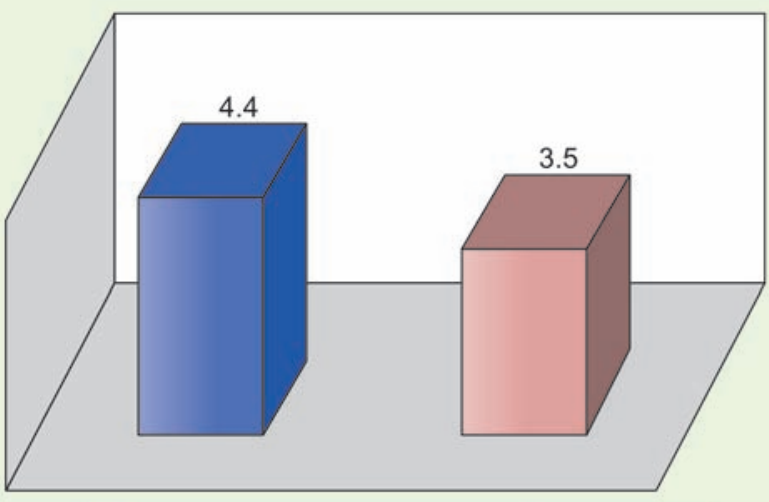

Zirconia abutment

Ti abutment

Graph 2: Visual analog scale
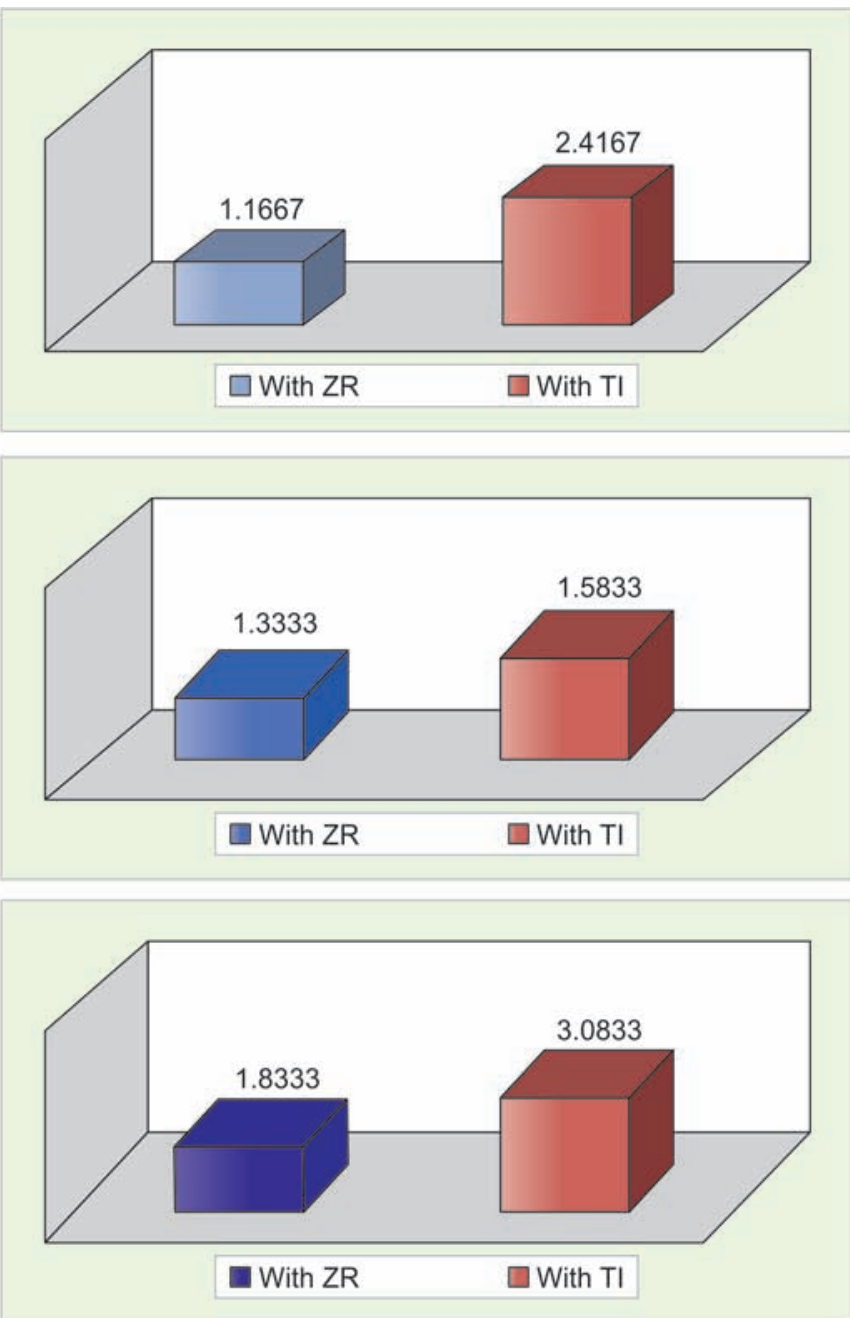

Graph 3: Copenhagen index score

interval [CI]: $0.4-52 \%$ ) for zirconia and 7.7\% (95\% CI: 4.7-12.5\%) for titanium abutments. Esthetic complications tended to be more frequent with metal abutments. ${ }^{25}$ Zirconia opacity has been useful in adverse clinical situations, e.g., for masking of dyschromic abutment teeth. Zirconia implant abutments can also be used to improve the esthetic outcome of implant-supported rehabilitations. ${ }^{35}$ The study done by Sailer et $\mathrm{al}^{44}$ had shown results not in accordance to results of this study. They showed that both crowns on zirconia and titanium abutments induced a similar amount of discoloration of the soft tissue compared with the gingiva of natural teeth. 


\section{CONCLUSION}

The study results suggested that zirconia abutments showed significant difference in terms of biological and esthetic outcomes when compared with titanium abutments. Zirconia abutments may be used as a viable alternative to currently available titanium abutments in implant-supported restorations, especially in the esthetic zone. There is a need for more long-term clinical studies so that zirconia abutments can be used as a viable alternative to titanium abutments.

\section{ACKNOWLEDGMENT}

Authors would like to thank their colleagues from the Army Dental Centre R\&R, Naval Institute of Dental Sciences, and INHS Asvini who provided insight and expertise that greatly assisted the research work.

\section{REFERENCES}

1. Osman RB, Swain MV. A critical review of dental implant materials with an emphasis on titanium versus zirconia. Materials 2015 Mar;8(3):932-958.

2. Adell R, Lekholm U, Rockler B, Brånemark PI. A 15-year study of osseointegrated implants in the treatment of the edentulous jaw. Int J Oral Surg 1981 Dec;10(6):387-416.

3. Glauser R, Sailer I, Wohlwend A, Studer S, Schibli M, Schärer P. Experimental zirconia abutments for implant-supported single-tooth restorations in esthetically demanding regions: 4-year results of a prospective clinical study. Int J Prosthodont 2004 May-Jun; 17(3):285-290.

4. Kohal RJ, Weng D, Bächle M, Strub JR. Loaded custom-made zirconia and titanium implants show similar osseointegration: an animal experiment. J Periodontol 2004 Sep; 75(9): 1262-1268.

5. Prestipino V, Ingber A. Esthetic high-strength implant abutments. Part I. J Esthet Dent 1993 Jan-Feb;5(1):29-36.

6. Prestipino V, Ingber A. Esthetic high-strength implant abutments. Part II. J Esthet Dent 1993 Mar-Apr;5(2):63-68.

7. Prestipino V, Ingber A. All-ceramic implant abutments: esthetic indications. J Esthet Dent 1996 Jan;8(6):255-262.

8. Bressan E, Paniz G, Lops D, Corazza B, Romeo E, Favero G. Influence of abutment material on the gingival color of implant-supported all-ceramic restorations: a prospective multicenter study. Clin Oral Implants Res 2010 Jun;22(6): 631-637.

9. Nakamura K, Kanno T, Milleding P, Örtengren U. Zirconia as a dental implant abutment material: a systematic review. Int J Prosthodont 2010 Jul-Aug;23(4):299-309.

10. Holst S, Blatz MB, Hegenbarth E, Wichmann M, Eitner S. Prosthodontic considerations for predictable single-implant esthetics in the anterior maxilla. J Oral Maxillofac Surg 2005 Sep;63 (9 Suppl 2):89-96.

11. Andersson B, Schärer P, Simion M, Bergström C. Ceramic implant abutments used for short-span fixed partial dentures: a prospective 2-year multicenter study. Int J Prosthodont 1999 Jul-Aug;12(4):318-324.

12. Andersson B, Taylor A, Lang B, Scheller H, Schärer $P$, Sorensen JA, Tarnow D. Alumina ceramic implant abutments used for single-tooth replacement: a prospective 1- to 3-year multicenter study. Int J Prosthodont 2001 Sep-Oct;14(5): 432-438.

13. Studer S, Wohlwend A, Schärer P. Ein Behandlungskonzept für die Implantatversorgung der Einzelzahnlücke unter Berücksichtigung parodontaler Aspekte bei Anwendung eines experimentellen Zirkonoxidabutments. Teil 2: Prothetische und zahntechnische Erfahrungen. Parodontologie 1996;9:97-118.

14. Wohlwend A, Studer S, Schärer P. Das ZirkonoxidabutmentEin neues vollkeramisches Konzept zur ästhetischen Verbesserung der Suprastruktur in der Implantologie. Quintessenz Zahntechnik 1996 Apr;22:364-381.

15. Abrahamsson I, Berglundh T, Glantz P-O, Lindhe J. The mucosal attachment at different abutments. An experimental study in dogs. J Clin Periodontol 1998 Sep;25(9):721-727.

16. Andersson M, Odén A. A new all-ceramic crown. Acta Odontol Scand 1993;21:59-64.

17. Meier R, Hauser-Gerspach I, Lüthy H, Meyer J. Adhesion of oral streptococci to all-ceramics dental restorative materials in vitro. J Mater Sci Mater Med 2008 Oct;19(10):3249-3253.

18. Zeng K, Odén A, Rowcliffe D. Flexure tests on dental ceramics. Int J Prosthodont 1996 Sep-Oct;9(5):434-439.

19. Hegenbarth EA. Procera aluminum oxide ceramics: a new way to achieve stability, precision, and esthetics in all-ceramic restorations. Quintessence Dent Technol 1996;19:21-34.

20. Lüthy, H. Strength and toughness of dental ceramics. In: Mörmann WH, editor. CAD/CAM in esthetic dentistry. Chicago (IL): Quintessence; 1996. p. 229-239.

21. Drouin, JM.; Cales, B. Yttria-stabilized zirconia ceramic for improved hip joint head. In: Proceedings of the seventh international symposium on ceramics in medicine, Turku, Finland. Oxford: Butterworth-Heinemann; 1994. p. 389-394.

22. Richter, HG.; Burger, W.; Osthues, F. Ziconia for medical implants: the role of strength properties. In: Proceedings of the seventh international symposium on ceramics in medicine, Turku, Finland. Oxford: Butterworth-Heinemann; 1994. p. 401-406.

23. Kelly JR, Nishimura I, Campbell SD. Ceramics in dentistry: historical roots and current perspectives. J Prosthet Dent 1996 Jan;75(1):18-32.

24. Scarano A, Piattelli M, Caputi S, Favero GA, Piattelli A. Bacterial adhesion on commercially pure titanium and zirconium oxide disks, an in vivo human study. J Periodontol 2004 Feb;75(2):292-296.

25. Manicone PF, Rossi Iommetti P, Raffaelli L. An overview of zirconia ceramics: basic properties and clinical applications. J Dent 2007 Nov;35(11):819-826.

26. Rimondini L, Cerroni L, Carrassi A, Torricelli P. Bacterial colonization of zirconia ceramic surfaces: an in vitro and in vivo study. Int J Oral Maxillofac Implants 2002 NovDec;17(6):793-798.

27. Nascimento C, da Rocha Aguiar C, Pita MS, Pedrazzi V, de Albuquerque RF Jr, Ribeiro RF. Oral biofilm formation on the titanium and zirconia substrates. Microsc Res Tech 2013 Feb;76(2):126-132.

28. Welander M, Abrahamsson I, Berglundh T. The mucosal barrier at implant abutments of different materials. Clin Oral Implants Res 2008 Jul;19(7):635-641.

29. LimaEM,KooH, Vacca-Smith AM,RosalenPL,DelBelCury AA. Adsorption of salivary and serum proteins, and bacterial adherence on titanium and zirconia ceramic surfaces. Clin Oral Implants Res 2008 Aug;19(8):780-785. 
30. Al-Ahmad A, Wiedmann-Al-Ahmad M, Faust J, Bächle M, Follo M, Wolkewitz M, Hannig C, Hellwig E, Carvalho C, Kohal R. Biofilm formation and composition on different implant materials in vivo. J Biomed Mater Res B Appl Biomater 2010 Oct;95(1):101-109.

31. Pae A, Lee H, Kim HS, Kwon YD, Woo YH. Attachment and growth behavior of human gingival fibroblasts on titanium and zirconia ceramic surfaces. Biomed Mater 2009 Apr;4(2):025005-025012.

32. van Brakel R, Meijer GJ, Verhoeven JW, Jansen J, de Putter C, Cune MS. Soft tissue response to zirconia and titanium implant abutments: an in vivo within-subject comparison. J Clin Periodontol 2012 Oct;39(10):995-1001.

33. Voiglo P, Fonzi F, Majzoub Z, Cordioli G. An in vitro evaluation of titanium, zirconia and alumina abutments with hexagonal abutments. Int J Oral Maxillofac Implants 2006 Jul-Aug;21(4):575-580.

34. Kim JS, Raigrodski AJ, Flinn BD, Rubenstein JE, Chung KH, Mancl LA. In vitro assessment of three types of zirconia implant abutments under static load. J Prosthet Dent 2013 Apr;109(4):255-263.

35. Sailer I, Philipp A, Zembic A, Pjetursson BE, Hämmerle $\mathrm{CH}$, Zwahlen M. A systematic review of the performance of ceramic and metal implant abutments supporting fixed implant reconstructions. Clin Oral Implants Res 2009 Sep;20(Suppl 4):4-31.

36. Gotfredsen K. A 10-year prospective study of single tooth implants placed in the anterior maxilla. Clin Implant Dent Relat Res 2012 Mar;14(1):80-87.

37. Fürhauser R, Florescu D, Benesch T, Haas R, Mailath G, Watzek G. Evaluation of soft tissue around single-tooth implant crowns: the pink esthetic score. Clin Oral Implants Res 2005 Dec;16(6):639-644.

38. Lee DW, Park K H, Moon IS. Dimension of keratinized mucosa and interproximal papilla between adjacent implants. J Periodontol 2005 Nov;76(11):1856-1860.

39. Kerstein RB, Castellucci F, Osorio J. Ideal gingival form with computer-generated permanent healing abutments. Compend Contin Educ Dent 2000 Oct;21(10):793-795.

40. Polson AM. The research team, calibration, and quality assurance in clinical trials in periodontics. Ann Periodontol 1997 Mar;2(1):75-82.

41. Mombelli A, van Osten MAC, Schürch E Jr, Lang NP. The microbiota associated with successful or failing osseointegrated titanium implants. Oral Microbiol Immunol 1987 Dec;2(4):145-151

42. Ekfeldt A, Fürst B, Carlsson GE. Zirconia abutments for single-tooth implant restorations: a retrospective and clinical follow-up study. Clin Oral Implants Res 2011 Nov;22(11): 1308-1314.

43. Hall D, Taylor RW, Jacobson A, Sadowsky PL, Bartolucci A. The perception of optimal profile in African Americans versus white Americans as assessed by orthodontists and the lay public. Am J Orthod Dentofacial Orthop 2000 Nov;118(5):514-525.

44. Sailer I, Zembic A, Jung RE, Siegenthaler D, Holderegger C, Hämmerle $\mathrm{CH}$. Randomized controlled clinical trial of customized zirconia and titanium implant abutments for canine and posterior single-tooth implant reconstructions: preliminary results at 1 year of function. Clin Oral Implants Res 2009 Mar;20(3):219-225. 